\title{
Lockdown Impact: Domestic Violence against Women and Girl
}

\author{
N. Rani*, K. Duhan, P. Kumari and Komal \\ I.C. College of Home Science, CCS HAU, HISAR, India \\ *Corresponding author
}

Keywords

Lockdown,

Domestic violence, Pandemic, Barriers, Effects of COVID19

\section{Article Info}

Accepted:

04 December 2020 Available Online: 10 January 2021
Governments across the world have responded to the COVID-19 pandemic by imposing restrictions on various activities of citizen. The Indian government alas imposed strict lockdown all over the country. The lockdown initially meant for 3 weeks has been extended thrice for a total duration of about 10 weeks. This review paper looks specifically at prevalence of domestic violence during lockdown. COVID-19 has a significant impact on individuals, families, and countries equally. People have to deal with the consequences of the infection as well as the preventive measures taken to control the infection such as isolation, social distancing, and restriction on movements. The lockdown has had completely different implications on women than men. Domestic violence (DV) is a gender-based violence that happens at homes and usually involves the spouse or partner or other family members. Increased rates of violence against women and children also reported during lockdown. Due to lockdown victims are distanced from their regular support systems or making it difficult for them to call out for help. A report of National Commission of Women (NCW) shows that within two weeks a $100 \%$ rise in complaints of domestic violence cases.

\section{Introduction}

Women and children are often in great danger in their families, where they should be safest. Today 'Home' is a place where they face terror and violence by someone who is very close to them, someone they should be able to trust. Women and girls victimized and suffer physically and psychologically. Women and girls are unable to make their own decisions, voice their own opinions or protect themselves and their children for fear of further repercussions. Their human rights are violated and their lives are stolen from them by the ever-present threat of violence. This review paper looks specifically at domestic violence during lockdown. The term 'domestic violence' includes violence by an intimate partner and by other family members wherever violence takes place and in any form.

Violence against women and girls continues to be a global problem that kills and tortures women - physically, psychologically, sexually and economically. It is one of the most dangerous for human rights, women and girls equality, security, dignity, self-worth, 
and their right to enjoy fundamental freedoms. Violence against women is present in every country, across boundaries of culture, class, education, income, ethnicity and age. Even though most societies proscribe violence against women, the reality is that violations against women's human rights are often sanctioned under the garb of cultural practices and norms, or through misinterpretation of religious tenets. Moreover, when the violation takes place within the home, as is very often the case, the abuse is effectively suppresses by the unspoken silence. According to UNFPA (2020), pandemics often lead to breakdowns of social infrastructures thus compounding the already existing weaknesses and conflicts. As a result, the existing gender inequality is worsened by the pandemic situations. It also increases the exposure of children and women to harassment and sexual violence when they try to procure necessities such as water, food, and firewood.

Worldwide women consider family as informal channel for their first point-ofreporting in the case of domestic violence. The first respondent is often from the family and the police the last (Jacob et al., 2019). In India; it is discovered that $33 \%$ of married women in the age group of 15-49 experienced physical, sexual, or emotional spousal violence. Of these women, only $14 \%$ sought help and $77 \%$ never spoke about it. Among those who sought help, $65 \%$ reported to the natal family and only $3 \%$ reported to the police (NFHS-4, 2015-16). Unfortunately, domestic violence cases are underreported across the world, especially in times of global emergencies like COVID-19.

With a rapid increase in the number of COVID-19 cases across the world in the past few months, several international organizations observe a global increase in domestic violence (DV) cases which is a result of physical distancing regulations and its following lockdowns. Many countries reported a 15-30\% hike in the number of distress calls received from women who were confined in closed spaces with abusive partners. Many studies show a direct link between times of crisis like these and interpersonal violence (Johnson et al., 2008). Pandemics provide an environment of fear and uncertainty that may intensify diverse forms of violence against women. Economic insecurity, financial instability, and isolation are also some of the factors that contribute to making domestic violence more prevalent. This pandemic time is become very hard to spend for many women and other deprived family members.

\section{Effect of 2020 COVID-19 lockdowns}

The Prime Minister of India announced a nationwide lockdown On 24 March 2020, to contain the spread of the Novel Corona virus. During the time of lockdown a progressive increase reported in the cases of domestic violence in India. Due to lockdown victims are distanced from their regular support systems or making it difficult for them to call out for help. A report of National Commission of Women (NCW) shows that within two weeks a $100 \%$ rise in complaints of domestic violence cases. A nationwide WhatsApp number was then launched by the NCW to provide an alternate method for women to report domestic abuse.

National Commission of Women monthly data shows some other truth about domestic violence. It showed an overall decrease in the complaints received during the months of lockdown in comparison to even the initial months of 2020 (Complaints received: January: 538, February: 523, March: 501, April: 377). However, the gradual relaxation of the lockdown saw a subsequent surge in the complaints. While 552 complaints were recorded in the month of May, June saw over 
730 complaints. This data shows that while the concern of a rapid increase in the domestic violence cases during the lockdown was valid, the instances were not actively reported. Because women were really unable to report crime which they were faced during lockdown. Researchers have observed a link between the prevalence of HIV epidemic and gender-based violence in India as well (Godbole and Mehendale, 2005, Silverman et al., 2008).

A report about rapid gender analysis on COVID-19 by CARE and International Rescue had expected gender-based violence to rise during pandemic and quarantines. The report had also recommended preparing and building on existing services for the victims of gender-based violence. The report further emphasized on the need to strengthen online services to provide psychological support and legal aid services (Haneef and Kalyanpur, 2020). According to Menendez et al., (2015), often women do not have rights over their sexual choices. Consequently, they experience sexual violence and the risk of exposure to the virus through the male carrier. Sexual and gender-based violence increases during crisis situations due to breakdown (Okur 2016). Thus, the victims often do not receive the adequate support, and the perpetrators get exempted from punishment. Also, according to the WHO global ethics unit (2016), gender roles affect all aspects of an endemic including interpersonal violence. It also emphasized the need of various services to minimize the risk of violence when people are quarantined at home or in institutions.

Jones and Isham (2020) also said that the lockdown during COVID-19 has granted greater freedom to abusers. Several media reports indicate a surge in cases of domestic violence in various countries. According to Kagi (12), though a drop was observed in the overall crime rates in Australia, the domestic abuse rates increased by $5 \%$. Some charities in Australia also raised concerns about COVID-19 misinformation being used by the offenders to further control and abuse the victims of domestic violence (Gearin $M$ and Knight B 2020). Researcher also (Allen and China 2020) reported that China witnessed a threefold increase in the cases of domestic violence after imposing quarantine. Different states in the United States also reported an increase of about 21-35\% in domestic violence (Wagers, 2020).

\section{Barriers to reporting complaint during pandemic lockdown}

The series of COVID-19 lockdowns in India reduced the opportunities of reporting of domestic violence cases. The lockdown harmed women by preventing them from moving to safer places in cases of violence and abuse. With men and women residing together for longer time periods, the privacy of women decreased and instances of violence rose. After noticing this situation a whatsapp number launched by the National Commission for Women but this number also had a limited reach as only $38 \%$ of women in India own phones and fewer have an internet connection, making this platform inaccessible to majority of women in the country. Biological family is usually the first point of contact for the women to share her problems. Due to lockdown women are not able to get essential support from the paternal family and also not facilitate self for filing a complaint to the police. The constant presence of the person responsible for domestic violence, made it difficult for the victims (women) to contact their first respondent which ultimately deterred them from reporting to institutionalized channels. Protection of women from any kind of violence under the Protection of Women from Domestic Violence Act had not been identified as an 
essential service during the lockdown by governing bodies. Hence, the protection officers were not able to visit households of victims, NGOs were not able to have physical interactions with them and the police officers being at the frontline in our effort to tackle COVID-19 were overstretched to help victims effectively.

A Delhi-based NGO has witnessed 50\% drop in calls on helpline numbers, while incidents of gender-based violence increases. This could be because of the fear of getting discovered by that person who did crime at home (Chandra 2020). According to Bradbury-Jones and Isham (2020), the lockdown imposed to deal with COVID-19 give greater freedom to abusers. It has become easier for the abusers to impose control strategies by restrictive the access of the sufferers to phones, internet, and other people. Gelder et al., (2020) also found that the lockdown restrict familiar support options. In an article (69), Rothman raised concerns about declaring sale of guns to be essential services in some states of the United States. This increases the likelihood of serious interpersonal violence. Fielding (2020) emphasized that the victims of domestic violence scared to visit a hospital for treatment of their injuries due to the fear of contracting the COVID-19 disease.

In conclusion the spread of the COVID-19 has produced countless of problems for the people to struggle with. In the lack of a vaccine and effectual treatment for this virus, the governments are forced to impose quarantines on infected person to reduce the spread of the virus. Though, this has resulted in an antilogy of social distancing, which includes issues such as economic insecurity, psychological problems, and separation. Although there have been researches exploring the impact of COVID-19, there is a lack of exact literature which pay stress on domestic violence. Rising incidents of gender violence during the pandemic is also an important the issue for discussion and review. COVID-19 has not only leaded to an increase in the cases of domestic violence but has detached them from their support networks and system. To decrease the prevalence of the domestic violence, it is essential to recognize the extent of gender-based violence, reframe related government policies, and to develop strong support networks. Special policies are necessary because domestic violence is a crime that takes place within the family between the people who involve emotionally, physically and economically to each other. Policies must take into account cultural, economic and political realities of the country. Policy approaches to victims are necessary for their success. There must be complimentary changes in policies. Make it easier for the victims to access policies/support system and, lastly, create awareness about the issue as well as the resources available to deal with domestic violence.

\section{References}

Jacob, Suraj, and Sreeparna Chattopadhyay, (2019): Speaking of Abuse The Pyramid of Reporting DV in India, ECONOMIC AND POLITICAL WEEKLY 53-62, 54

National Family Health Survey (NFHS-4), 201516: India. INTERNATIONAL INSTITUTE FOR POPULATION SCIENCES (IIPS) and ICF 2017. Mumbai: IIPS.

Johnson, H. \& Ollus, N. \& Nevala, Sami (2008) Violence against women: An international perspective 10.1007/978-0-387-73204-6 (2008).

UNFPA (2020, March 20): As Pandemic Rages, Women and Girls Face Intensified Risks.. Retrieved from: https://www.unfpa.org/news/pandemicrageswomen-and-girlsface-intensified-risk.

Godbole S and Mehendale S. (2005): HIV/AIDS epidemic in India: risk factors, risk behavior \& strategies for prevention \& 
control. Indian Journal of Medical Researches. 121:356-68.

Silverman J.G., Decker M. R., Sagurti N., Balaiah D. and Raj A. (2008): Intimate partner violence and HIV infection among married indian women. $J$ Am Med Assoc. 300:70310. doi: 10.1001/jama.300.6.703

Haneef C. and Kalyanpur A. (2020): Global Rapid Gender Analysis for COVID 19. New York, NY: CARE and International Rescue Committee.

Menéndez C., Lucas A., Munguambe K. and Langer A. (2015): Ebola crisis: the unequal impact on women and children's health. Lancet Global Health. 3:e130. doi: 10.1016/S2214-109X(15)70009-4

Okur P. (2016): Sexual and reproductive health and rights of people on the move. MT Bull Netherl Soc Trop Med Int Health. 54:8-9. Available online at: https://www.rutgers.nl/sites/rutgersnl/files/ PDF/nvtg_mt_2016-8-9.pdf

World Health Organizations Global Ethics Unit. (2016): WHO Ethical Guidance for Managing Epidemic Outbreaks. In: 11th Global Summit of National Ethics/ Bioethics Committees, Conference Report, Global Health, Global Ethics, Global Justice. Berlin. p. 118-151.

Schneider D., Harknett K. and McLanahan S. (2016): Intimate partner violence in the great recession. Demography. 53:471-505. doi: 10.1007/s13524-016- 0462-1

Kagi J. (2020): Crime Rate in WA Plunges Amid Coronavirus Social Distancing Lockdown Measures. ABC News Australia.. Available online at: https://www.abc.net.au/news/2020-0408/coronavirus-shutdown-seescrimeratedrop-in-wa/12132410 (accessed 10 April, 2020).

Gearin M. and Knight B (2020): Family Violence Perpetrators Using COVID-19 as a Form of Abuse We Have Not Experienced Before. ABC News Australia. Retrieved from: https://www.abc.net.au/news/202003-29/coronavirus-family-violence-surgein-victoria/12098546

Allen-Ebrahimian B. (2020): China's Domestic Violence Epidemic, Axios. Retrieved from: https://www.axios.com/chinadomesticviolencecoronavirusquarantine7b00c3ba-35bc-4d16-afdd-b76ecfb28882. html.

Wagers S. (2020): Domestic Violence Growing in Wake of Coronavirus Outbreak. The Conversation. Retrieved from: https://theconversation.com/domesticviole nce-growing-in-wake-ofcoronavirus-outbreak-135598.

Chandra J. (2020): COVID 19 Lockdown Rise in Domestic Violence, Police Apathy: NCW. The Hindu. Retrieved from: www.thehindu.com/ news/national/COVID-19-lockdownspike-in-domestic-violencesays ncw/article 31238659 .ece

Jones B.C and Isham L.(2020): The pandemic paradox: The consequences of COVID-19 on domestic violence. $J$ Clin Nurs. 29:2047-49.doi: 10.1111/jocn. 15296

Gelder V. N., Peterman A., Potts A., O'Donnell M., Thompson K., and Shah N (2020):. COVID-19: Reducing the risk of infection might increase the risk of intimate partner violence. E. Clinical Medicine. (2020) 21:1-2.doi: 10.1016/j.eclinm.2020.100348

Fielding S. ((2020): In Quarantine With an Abuser: Surge in Domestic Violence Reports Linked to Coronavirus. The Guardian. (2020, April 8). Retrieved from https:// Www.theguardian.com/usnews/2020/apr/03/coronavirusquara ntineabuse-domestic violence

\section{How to cite this article:}

Rani, N., K. Duhan, P. Kumari and Komal. 2021. Lockdown Impact: Domestic Violence against Women and Girl. Int.J.Curr.Microbiol.App.Sci. 10(01): 259-263. doi: https://doi.org/10.20546/ijcmas.2021.1001.031 